UDC 94(570+471)-054.73“1914/1918"

DOI 10.24919/2519-058X.18.226510

\title{
Tetiana KOVALENKO
}

PhD (History), Senior Lecturer of the Department of Social and Economic Disciplines of International Education Institute for Study and Research and the Department of Modern and Contemporary History of School of History of V. N. Karazin Kharkiv National University, 4 Svobody Square, Kharkiv, Ukraine, Ukraine, postal code 61022 (teti.kovalenko@gmail.com)

ORCID: 0000-0001-8309-8071

ResearcherID: AAH-6318-2019

\section{Тетяна КОВАЛЕНКО}

кандидат історичних наук, старший викладач кафедри соџіально-економічних дисциплін Навчально-наукового інституту міжнародної освіти та кафедри нової та новітньої історії історичного факультету Харківського національного університету імені В. Н. Каразіна, пл. Свободи 4, м. Харків, Україна, індекс 61022, (teti.kovalenko@gmail.com)

Bibliographic Description of the Article: Kovalenko, T. (2021). War beyond the Frontline: Refugees in Internal Governorates of the Russian Empire during World War I. Skhidnoievropeiskyi Istorychnyi Visnyk [East European Historical Bulletin], 18, 98-106. doi: 10.24919/2519-058X.18.226510

\section{WAR BEYOND THE FRONTLINE: REFUGEES IN INTERNAL GOVERNORATES OF THE RUSSIAN EMPIRE DURING WORLD WAR I}

\begin{abstract}
The purpose of the research is to discover the causes and character of mass migration and refugees at the territory of the Russian Empire during World War I, as well as to analyze the state policy in the field of refugees' care and to define the role of community and national aid organizations in it. The research methodology is based on the principles of historicism, objectivity, system-formation, and the use of general scientific (analysis, synthesis, retrospective, perspective, generalization) and special historical (historical genetic, historical typological, historical systemic, historical comparative) methods. The scientific novelty of the article is that the number of refugees, the legislative regulation of the organization of help to these victims of war, the conditions and effectiveness of the work of the state, community and national committees in the field of refugee care, and some individual components of their daily lives were determined on the basis of previously unknown archival and printed documents. The Conclusions. The consequences of the mass and forced evacuation of the population from Western provinces of the Russian Empire were tragic. The authorities themselves initiated the local residents eviction, explaining it by the demands of the war, and then took responsibility to provide them with aid and financed it. The counting on their quick return home after several successful military operations turned out to be wrong, and millions of people turned into refugees remained helpless and in need of help for a long time. The situation required not only state institutions to be involved in the work, because the state alone could not cope with the problem. Refugee care was held by the Russian community organisations and national committees of aid to the victims of the war (Ukrainian, Polish, Lithuanian, Latvian, etc.). Despite the work undertaken by the Russian authorities in the field of providing comprehensive social support to refugees, cooperation between the authorities and various aid organizations has been complicated, but not only by incomprehensible legislation. The cumbersome bureaucratic apparatus of the Russian Empire, the crisis of the authorities hampered promptness, while the refugees demanded immediate assistance.
\end{abstract}

Key words: refugees, aid organizations, the Russian Empire, World War I, state, community and national committees. 


\title{
ВІЙНА ЗА МЕЖАМИ ФРОНТУ: БІЖЕНЦІ У ВНУТРІШНІХ ГУБЕРНІЯХ РОСІЙСЬКОЇ ІМПЕРІЇ В РОКИ ПЕРШОЇ СВІТОВОЇ ВІЙНИ
}

\begin{abstract}
Анотація. Мета дослідження - визначити причини та характер масового біженства на території Російської імперії за часів Першої світової війни, а також проаналізувати державну політику в галузі опіки над біженцями й визначити в ній роль громадських та національних організацій допомоги. Методологія дослідження трунтується на приниипах історизму, об'єктивності та системності, а також на використанні загальнонаукових (аналіз, синтез, ретроспектива, перспектива, узагальнення) та спеціально-історичних (історико-генетичний, історико-типологічний, історико-системний, історико-порівняльний) методів. Наукова новизна статті полягає у тому, щзо на основі невідомих раніше архівних та друкованих документів з'ясовано кількість біженців, правову регламентацію організачії допомоги ичим жертвам війни, умови та ефективність роботи державних, громадських та національних комітетів у сфері опіки біженців, окремі складові їх повсякденного життя. Висновки. Наслідки масової примусової евакуації населення західних губерній Російської імперї та часто безпорадність російської влади, яка спочатку ініціювала та профінансувала виселення місиевих мешканиів, пояснюючи його вимогами війни, а потім взяла на себе організацію ӥм допомоги, були катастрофічними. Розрахунок на їхнє швидке повернення додому після кількох вдалих воєнних операцій виявився хибним, а мільйони перетворених на біженців людей вимагали залучення до роботи не тільки державних установ. Опікою біжениів займались російські громадські організації та начіональні комітети допомоги жертвам війни (польські, литовські, латиські тощо). Незважаючи на роботу проведену російською владою в сфері забезпечення всебічної сочіальної допомоги біжениям, співпраця між ланками влади та різними організаціями допомоги була ускладнена, але не тільки небездоганним законодавством. Громіздкий бюрократичний апарат Російської імперї, криза органів влади заважали оперативності, тоді як біженці вимагали негайної допомоги.

Ключові слова: біжениі, організачія допомоги, Російська імперія, Перша світова війна, державні, громадські, національні комітети.
\end{abstract}

The Problem Statement. One of the consequences of World War I was the civilian mass migration and refugees. The United Kingdom, France and the Netherlands took care of Belgian refugees. The problem also emerged in Germany, where the entry of the French army into Alsace on the Western Front and the Russians into Prussia on the Eastern Front led to the appearance of refugees. The Austro-Hungarian authorities expelled Eastern Galicia inhabitants of towns and villages that were the part of the battle area zone. However, it was in the Russian Empire where refugee received unprecedented numbers of resettled people and in most cases it was forced.

The purpose of publication is to to discover the causes and character of mass refugees' migration at the territory of the Russian Empire during World War I, as well as to analyze the state policy in the field of support of refugees and to determine in it the role of community and national aid organizations.

The Analysis of Recent Researches. Refugee (the term used was "bezhenstvo" or "refugeedom") in the Russian Empire during World War I was studied in the Ukrainian historiography (Lykhachova, 2010; Serdiuk, 2002; Zhvanko, 2012, etc.), by the Belarusian (Samatyya, 2003), by the Polish (Korzeniowski, Mądzik, Tarasiuk, 2007), British (Gatrell, 1999, 2000, 2015), by the Russian (Kurtsev, 1999, Shcherov, 2000, Tsovyan, 2005, etc.) researchers. In their works, scholars cover a large number of people - both refugees and all those involved in helping them. There exists a trend toward regionalization of a study. However, the subject matter is extremely multifaceted, that is why so many aspects are still covered by scholars insufficiently. It has a diverse source base, which is widely represented by the Ukrainian, Belarusian, Polish, Lithuanian, Russian archives, periodicals, memoirs, legal acts waiting for researchers. 
The Basic Material Statement. Since the beginning of the military conflict, the inhabitants of Western provinces of the Russian Empire, frightened by the deepening of the front line, hastily fled their homes. People, mostly peasants, were hiding in woods or in neighboring villages outside the enemy's fire. They did not want to stay far from home (State Archive of the Russian Federation, f. 651, d. 1, c. 39, p. 17). Among the inhabitants of Western provinces of the Russian Empire there was only a small number of people, who moved to the interior regions of the country (on their own initiative and at their own expense). In most cases, they were housed with relatives or rented temporary accommodation. Few of them, who were suffering from need, were helped by local people and charitable organizations (e.g., Komitet Eye Imperatorskogo Vysochestva Velikoy Knyazhny Tatiany Nikolayevny po okazaniyu vremennoy pomoshchi postradavshim ot voyennykh deystviy (the Committee of Her Imperial Highness the Grand Duchess Tatiana Nikolaevna for the Temporary Relief of Victims of War, hereinafter referred to as the Tatiana Committee) that was founded on September 14, 1914). Thus, with the exception of the eviction of people of Russia belligerent states and the Jews because of spying charges by the summer of 1915, a spontaneous shortage of refugees prevailed among the population of the frontline zone, which was caused by the voluntary desire of people to stay away from military actions.

However, in the summer of 1915 , refugee resettlement took a completely different character. The fact is that under the conditions of war, extraordinary powers were given to the Russian High Command by law, and therefore the right to control fully all spheres of life at the theater of military action. Consequently, after the beginning of the Russian army retreat after its defeat from the Austro-Hungarian and German troops in the spring and summer of 1915, it became possible for Stavka (the High Command of the armed forces in the Russian Empire) to make a decision to evacuate the population of the frontier provinces. The fact is that the Russian High Command believed that the enemy, who got to the devastated area, was experiencing difficulties in food, troop housing, etc.

"What cannot be taken away is to be destroyed", - stated in the military order (Russian State Military Historical Archive - RSMHA, f. 2005, d. 1, c. 42, p. 9). Particular emphasis was placed on men of conscription age, who were considered to be potential soldiers (those who could be mobilized into the enemy's army). The order of the house-to-house and forced eviction of residents of the frontier provinces led to the fact that the refugee had acquired a scale to which the state was not ready. Finally, on June 26, 1915 the Supreme Commander ordered to cancel total forced eviction and the destruction of the property of the frontline residents immediately. However, exceptions were provided for situations where combat conditions and military objectives required it (RSMHA, f. 2005, d. 1, c. 42, p. 7). Therefore, there was room for arbitrariness of individual ranks.

The decision of the military immediately provoked ambiguous reaction in the Russian political circles. Negative effects of forced refugee were emphasized at the meetings of the Council of Ministers. The Minister of Internal Affairs Nikolay Shcherbatov fairly noted: "Women and children will leave their houses together with men. Millions will come to us to starve", - at the same time, cynically adding: "May better die under the German's heel" (Galperina, 1999, p. 260).

Evacuating the population of the frontline provinces, the authorities counted on their rapid return home. "Everyone is convinced that the territories captured by the enemy will soon return to us," - said the head of the Tatiana Committee in late September of 1915 Aleksey Neydhardt (SARF, f. P-3333, d. 2, c. 1, p. 29). In general, armed forces High Command of the belligerent 
states was confident of a short duration of the military actions. Generals of both sides supposed that the future conflict will take several weeks. The illusions about the quick re-evacuation of refugees were gradually dispelled. Already in November of 1915, there was no doubt that refugees could not be considered "short-term guests" (Iz deyatelnosti, 1915, p. 63). Already in the spring of 1916 refugees had one inexpugnable desire: to get home as soon as possible.

The Law on Ensuring the Needs of Refugees was adopted on August 30, 1915, from that time until November of 1917 the document defined the state care policy for refugees. A separate section of the document was The Regulations on Ensuring the Needs of Refugees, which regulated the basics of public policy in this field. Article 1 of the Regulation provided the definition of the term "refugee" by stating that he or she is "a person who has left the areas threatened or already occupied by the enemy or this person is evicted by military or civil authorities from the area of military action". Refugee status also got "citizens from Russia's belligerent states", except for the people evicted from the area of military actions under the police surveillance (Zakony, 1916, p. 3).

The granting of refugee status to "citizens from Russia's belligerent states" concerned the subjects of the Ottoman and Austro-Hungarian empires - Armenian refugees from Turkey and residents of Eastern Galicia. The first started arriving in the Caucasus from the end of 1914 (because of the Turks violence). In 1915 the evacuation continued. Eastern Galicia became a part of Russia at the beginning of the war as a result of military operations that were successful for the Russian army. After the accession on the territory of the region General Government of Galicia and Bukovyna was formed (headed by Georgiy Bobrinsky). National and spiritual kinship with the Galician-Ruthenian people was declared in the society of the Russian Empire, while Russian nationalists claimed that Galicia was "primordial Russian land", inhabited by the "Russian" people (Haid, 2017, p. 207). Anyway, all those who came from there formally remained citizens of the Austro-Hungarian Empire and the Turkish Empire, the states with which the Russian Empire was at war. Giving the Galicians and the Turkish Armenians status of refugees, the Russian government has committed to provide them with everything they needed (about Russian government policy in relation to citizens of hostile states and the Russian citizens recognized unreliable because of their nationality or ethnic origin, see Lohr, 2003).

The inconsistency of that time and contemporary interpretation of the term "refugee" draws attention. Nowadays, the Convention Relating to the Status of Refugees (1951) and amendments to the Protocol Relating to the Status of Refugees (1967), developed on the initiative of the United Nations Organization, became generally accepted in international law. According to these documents, a refugee is a person "owing to a well-founded fear of being persecuted for reasons of race, religion, nationality, membership of a particular social group or political opinion, is outside the country of his nationality and is unable or, owing to such fear, is unwilling to avail himself of the protection of that country; or who, not having a nationality and being outside the country of his former habitual residence as a result of such events, is unable or, owing to such fear, is unwilling to return to it" (Convention, n. d., p. 3). The latest the Global Compact for Migration was formally endorsed by the United Nations General Assembly in 2018, and in particular, it relies on the Convention Relating to the Status of Refugees of 1951 (Zhvanko, 2019, pp. 93-95).

The Ukrainians, the Belarusians, the Poles, the Russians, the Latvians, the Lithuanians were the subjects of the Russian Empire. They did not cross the state border (they were mostly displaced by military orders) and were not prosecuted on the grounds listed in the 
Convention and the Protocol. But during World War I, there were no legal regulations to define and protect this category of population. The novelty of refugee status often blindsided politicians, professionals, and ordinary citizens - all those, who sought to determine their place in the country's traditional social structure. While their number required the rapid creation of a legal framework to provide refugees with their crucial needs, the regulation of the transition from charitable support to a comprehensive and multifaceted state aid system.

Somewhat different experience in terms of legislative regulation was gained by the AustroHungarian authorities, who were also evicting Eastern Galicia residents of cities and villages that were the part of the combat actions (especially in the spring of 1916 due to the so-called Brusilov Offensive). The term "vyselentsi" or "displaced people" was used in relation to the victims. The aid was provided at the expense of the Austro-Hungarian treasury (Central State Historical Archive of Ukraine in Lviv, f. 397, d. 1, c. 6, pp. 1-3). Generally, up to 2 million civilians were internally displaced between 1914 and 1918 in the Austro-Hungarian Empire (Thorpe, 2011, p. 103), which began the war on two fronts in 1914 - against Serbia in the Balkans and against Russia in the east. Already in May of 1915 with the entry of Italy into the war, the third front added.

Determining the number of refugees who settled in the Russian Empire interior provinces, we should pay attention to the fact that the official data are mainly related only to those, who needed help. In other words, all those, who could take care of themselves (though it was a minority) were out of registration. Refugees, especially children and the elderly, who died while moving because of illnesses (typhus, diphtheria), cold, severe conditions of movement, remain unaccounted. Therefore, it is almost impossible to determine the exact number of these people.

The mass arrival of refugees to the Russian Empire interior provinces began in July August of 1915, reached its peak in September - October and almost ended in December of that year. An example is the number of refugee moving cards issued in Kharkiv province. In October of 1915 it was 4 500, in December of 1915 - 1 400, in January of 1916 - 1600 , in February of 1916 - 500, in May of 1916 - 381, September of 1916 - 60, in October of 1916 - 52, in November of 1916 - in total 19 (Kharkiv Region State Archive - KRSA, f. 18, d. 21, c. 225 , p. 5.). During 1916 - 1917, only a small number of refugees were moved with family reunion purpose. But the movement took place only with the permission of the governor of the destination territory, and such refugees were not deprived of financial aid only if the total number of those, who had already received it did not exceed 50\% (according to the Ministry of Interior Affairs circular on June 24, 1916). The rule remained in force after the February Revolution (KRSA, f. 18, d. 21, s. 153, p. 74; KRSA, f. 18, d. 21, c. 225, p. 16; Central State Historical Archive of Ukraine in Kyiv - CSHAUK, f. 917, d. 1, c. 15, p. 172).

The number of refugees was periodically calculated during $1915-1918$ by special organizations, representatives of the Russian authorities, the Provisional Government, and later the Bolshevik leadership. However, the set data were never the same. According to the estimates of the Tatiana Committee, which was considered to be an official body for registration of refugees, on December 20, 1915, at the territory of the Russian Empire without the Transcaucasia 2706309 refugees were registered, which represented 1,83\% of the indigenous population of these territories. Out of them, 2496640 people settled in the European Russia provinces (2,06\% of the local population), while the others settled in Siberia, the Caucasus and Central Asian regions (Lubny-Gertsyk, 1926, p. 23).

On May 1, 1916, the Tatiana Committee recorded 3095604 refugees, 564832 of which lived in provincial cities (KRSA, f. 18, d. 21, c. 142, p. 5). The Otdel po Ustroystvu Bezhentsev (the Department for the Provision of Refugees) of the Vserossiyskiy Zemskiy 
Soyuz Pomoshchi Bolnym i Ranenym Voinam (the All-Russian Zemstvo Union of Aid to Sick and Wounded Warriors (hereinafter referred to as the Zemstvo Union)) and the Vserossiyskiy Soyuz Gorodov (the All-Russian Union of Towns (hereinafter referred to as the Union of Towns)) recorded 3,2 million refugees (RSMHA, f. 2005, d. 1, c. 42, p. 537). Analyzing the number of people, who fell into the category of refugees, the scholar Peter Gatrell says they accounted for 5\% of the total population of the Russian Empire (Gatrell, 2000, p. 38).

The most populated province according to the amount of refugees was the Katerynoslav province $(9,23 \%$ of the total number of refugees in the Russian Empire). It is worth noting that statisticians of that time considered not only the Russians, but also the Ukrainians and the Belarusians to be the "Russian refugees" and this group of refugees was the largest in terms of numbers. The Poles ranked second, i.e., $17-20 \%$ of the total number of refugees of all nationalities (more statistics in Lykhachova, 2010, pp. 67-72).

Aid to refugees was implemented under the general guidance of the Osoboe Soveshchanie po Ustroystvu Bezhentsev (the Special Council for the Provision of Refugees), which was subordinated to the Ministry of Internal Affairs. The state took charge of all the costs of meeting the refugee needs. The Minister of Internal Affairs as the head of the Special Council for the Provision of Refugees managed all state credits (Zakony, 1916, pp. 3-4). The institution included: members of the State Council and the State Duma; representatives of ministries (military, foreign affairs, interior affairs, finance, education, lines of communications, commerce and industry) as well as other government committees. In addition, a representative from the Tatiana Committee and the Russian Committee of the Red Cross, the Zemstvo Union and the Union of Towns, as well as leading national committees of refugees' support took part in the work of the Special Council for the Provision of Refugees. In practice, such numbers only hindered prompt decision-making, while life required immediate solving of many issues.

Locally, rural and urban councils of the Russian community organizations, i.e., the Zemstvo Union and the Union of Towns, were in charge of refugees, with the right to involve both community leaders and refugees at their own discretion. Heads of the provincial committees were appointed by the Minister of Internal Affairs. Country, city and district inspectors were elected by the provincial committees (Zakony, 1916, p. 7). At the same time, the issue of interaction between central and local authorities remained without attention. In the future, this delayed the aid to refugees and sometimes even negated the efforts of local committees. Due to the inflexibility of the Russian Empire bureaucracy, funds were not provided in time, and the resolutions of the Special Council for the Provision of Refugees could be kept for months at various instances.

Another important issue left unattended by lawmakers was the definition of the role of the Zemstvo Union and the Union of Towns in the refugee social protection process. De jure government ensured committees' work in the Special Council for the Provision of Refugees, but de facto it was impossible to influence its decisions (the state institution included only one representative from these organizations). So while Zemstvo Union and the Union of Towns were in charge of refugees, they accurately implemented instructions and circulars of to the Ministry of Internal Affairs. The reason was that the government saw a political opponent in the All-Russian Zemstvo Union and the Union of Towns during all the time of their existence, but the situation required to transfer some powers to them. The Russian state could not cope with the aid to the millions of refugees alone.

Of great importance was the fact that the state contributed to the work of national committees of refugees support (Ukrainian, Polish, Lithuanian, Latvian, Armenian, etc.). 
They were an acceptable alternative to the Russian community organizations, which were considered to be a political opponent (the Zemstvo Union and the Union of Towns). And it was not the last thing that made the authorities encourage their work. Moreover, national committees had virtually free rein to claim the refugee as an emblematic figure of national victimhood, who might yet be saved on the nation's behalf (Gatrell, 2015, p. 700).

Some of them appeared at the beginning of World War I on the initiative of the local intelligentsia. In particular, this is how the Towarzystwo Pomocy Biednym Rodzinom Polakow Uczestniczących w Wojnie oraz Zubozalej przez Wojne Ludnosci Polskiej (Polskie Towarzystwo Pomocy Ofiarom Wojny, the Community for Aid to Poor Families of Poles Participating in the War and the Polish Population Impoverished by the War, the Polish Society for Assistance to War Victims) was founded in Petrograd in September of 1914 on the initiative of the Poles, who lived there before the war. The Committee was headed by a manufacturer Vladyslav Zhukovsky. Henryk Swiecicki - the State Duma deputy - became one of the Vice-Presidents (CSHAUK, f. 917, d. 1, c. 48, p. 1). Other national committees such as the Centralny Komitet Obywatelski Krolestwa Polskiego w Rosji (Central Citizens' Committee of the Kingdom of Poland in Russia) were evacuated in the summer of 1915 along with a major wave of refugees' movement. That one began its work in September of 1914 in Warsaw under the leadership of the Warsaw Governor-General Dmitry Lyubimov to help civilians in the Kingdom of Poland provinces affected by war (CSHAUK, f. 707, d. 165, c. 111, p. 3; see also Korzeniowski, Mądzik \& Tarasiuk, 2007, pp. 51-109).

The Tatiana Committee played an important role in the number of refugee aid organizations. It was a semipublic organization under the patronage of the Russian Emperor's daughter Grand Duchess Tatiana Nikolaevna. Her protection provided the committee with financial support from the government and at the same time made it possible to unite public and private initiative under "high name". An important element in the committee's activities was the provision of funds for the work of other refugee organizations, including national committees (Lykhachova, 2010, pp. 104-117).

It is important to add that the policy of the state determined the attitude to the moved population and in the society. As a result, refugees got aid not only from the treasury, but also from individuals' donations. Periodicals and other printed materials, which were saturated with desperate stories about the hard refugee fate, inhuman suffering, poverty, hopelessness, also shaped attitude to them in the Russian society. Refugee - "the misfortune that fell on the part of the empire's population as a result of the enemy invasion", was often associated with natural disasters (Deyatelnost, 1916, p. 10). As a result, an image of a suffering person deprived of civil rights, the object of various demonstrations of public activity and humanitarian aid emerged. And such information policy was effective, because during 1915 - 1916 there was a charity upsurge. However, since the second half of 1916, the state policy had shown a tendency to reduce the cost of keeping refugees as much as possible. There were objective reasons for this: lack of political stability, financial and economic, food crisis, and exhaustion of a protracted war. The attitude of the local population towards refugees since the second half of 1916 became cold and negative, and they began to be considered a burden.

The Conclusions. Thus, the consequences of the forced mass evacuation of the population of the Russian Empire Western provinces were grave. The authorities themselves initiated the local residents eviction, explaining it by the demands of the war, and then took responsibility to provide them with aid. However, counting on their quick return home after several successful military operations turned out to be wrong, and millions of refugees remained 
helpless and in need of help for a long time. This process was distinctive for all frontier provinces of the Russian Empire, i.e., parts of the territories of modern Poland, Belarus, Latvia, Lithuania, Ukraine. Refugees of different nationalities were registered in all interior regions of the Russian Empire.

The situation required not only state institutions to be involved in the work, because the state alone could not cope with the problem. Incorporating in refugee organizations such community organizations as the Zemstvo Union and the Union of Towns was not typical of the Russian reality. At the same time, the Russian authorities empowered national committees to help the victims of the war, which were opposed to unions. All of them carried out a similar range of tasks: were in charge of refugee housing, financial help, clothing, and footwear, creation of shelters, dormitories, canteens, and educational institutions. The chairmanship of refugee case of the Ministry of Internal Affairs reported about the state's interest in maintaining control.

Despite the work undertaken by the Russian authorities providing comprehensive social aid to refugees, cooperation between the authorities, charities, public and national organizations was complicated, but not only by incomplete legislation. Unmanageable bureaucratic apparatus of the Russian Empire, the crisis of the authorities hindered the promptness, while refugees were in need of immediate help.

Acknowledgments. We are grateful to the members of the editorial board and reviewers for the advice, given during the preparation of the article for publishing.

Funding. The author received no financial support for the research, authorship, and/or publication of this article.

\section{BIBLIOGRAPHY}

Convention. (n. d.). Convention and Protocol Relating to the Status of Refugees. URL: http://www. unhcr.org/protection/basic/3b66c2aa10/convention-protocol-relating-status-refugees.html [in English]

Derzhavnyi arkhiv Kharkivskoi oblasti [Kharkiv Region State Archive - KRSA]

Deyatelnost. (1916). Deyatelnost Komiteta Ee Imperatorskogo Vysochestva Velikoy Knyazhny Tatiany Nikolayevny [Activities of the Committee of Her Imperial Highness the Grand Duchess Tatiana Nikolaevna for the Temporary Relief of Victims of War]. Izvestiya Komiteta Ee Imperatorskogo Vysochestva Velikoy Knyazhny Tatiany Nikolayevny po okazaniyu vremennoy pomoshchi postradavshim ot voyennykh deystviy - News of the Committee of Her Imperial Highness the Grand Duchess Tatiana Nikolaevna for the Temporary Relief of Victims of War, 2, 10-12. [in Russian]

Galperina, B. D. (Ed.). (1999). Sovet ministrov Rossiyskoy imperii v gody Pervoy mirovoy voyny. Bumagi A. N. Yakhontova (zapiski zasedaniy i perepiska) [The Council of Ministers of the Russian Empire during the First World War. Papers by A. N. Yakhontov (notes of meetings and correspondence)]. S.-Peterburg: Dmitrij Bulanin, 558 p. [in Russian]

Gatrell, P. (1999). A Whole Empire Walking: Refugees in Russia During World War I. Bloomington: Indiana University Press, 318 p. [in English]

Gatrell, P. (2000). Domestic and international dimensions of population displacement in Russia, 1914 - 1918. In S. Pons, \& A. Romano (Eds.), Russia in the Age of Wars 1914 - 1945 (pp. 37-52). Milano: Feltrinelli. [in English]

Gatrell, P. (2015). Tsarist Russia at War: the View from Above, 1914 - February 1917. The Journal of Modern History, 87 (3), 668-700. doi: 10.1086/682414 [in English]

Gosudarstvennyy arkhiv Rossiyskoy Federatsii [State Archive of the Russian Federation-SARF]

Haid, E. (2017). Galicia: A Bulwark against Russia? Propaganda and Violence in a Border Region during the First World War. The Journal of Modern History, 24 (2), 200-213. doi: 10.1080/13507486.2016.1257574 [in English]

Iz deyatelnosti. (1915). Iz deyatelnosti otdela po ustroystvu bezhentsev zemskogo i gorodskogo soyuzov [From the Activities of the Department for the Provision of Refugees of the Zemstvo Union 
and Union of Towns]. Izvestiya Glavnogo komiteta Vserossiyskogo zemskogo soyuza pomoshchi bolnym i ranenym voinam - News of the Main Committee of the All-Russian Zemstvo Union of Aid to Sick and Wounded Warriors, 27, 60-88. [in Russian]

Korzeniowski, M., Mądzik, M. \& Tarasiuk, D. (2007). Tułaczy los. Uchodźcy polscy w Imperium Rosyjskim $w$ latach Pierwszej wojny światowej [Wandering Fate. Polish Refugees in the Russian Empire during the First World War]. Lublin: UMCS, 238 p. [in Polish]

Kurtsev, A. N. (1999). Bezhentsy Pervoy mirovoy voyny v Rossii (1914 - 1917) [Refugees of World War I in Russia (1914 - 1917)]. Voprosy istorii-Questions of History, 8, 98-114 [in Russian]

Lohr, E. (2003). Nationalizing the Russian Empire: the campaign against enemy aliens during World War I. Cambridge, Mass.: Harvard University Press, 256 p. [in English]

Lubny-Gertsyk, L. I. (1926). Dvizheniye naseleniya na territorii SSSR za vremya mirovoy voyny $i$ revolyutsii [Movement of the Population on the Territory of the USSR during the World War and Revolution]. Moscow: Planovoye khozyaystvo, 124 p. [in Russian]

Lykhachova, T. M. (2010). Polski bizhentsi v Rosii (serpen 1914 r. -lystopad 1917 r.) [Polish Refugees in Russia (August 1914 - November 1917)] (Candidate's thesis). Kharkiv. [in Ukrainian]

Rossiyskiy gosudarstvennyy voyenno-istoricheskiy arkhiv [Russian State Military Historical Archive-RSMHA]

Samatyya, V. R. (2003). Problema bezhentsev v Belarusi v gody Pervoy mirovoy voyny [The Problem of Refugees in Belarus during the First World War]. Belorusskiy zhurnal mezhdunarodnogo prava $i$ mezhdunarodnykh otnosheniy - Belarusian Journal of International Law and International Relations, 2, 71-74. [in Russian]

Serdiuk, O. V. (2002). Bizhenstvo v Ukraini pid chas Pershoi svitovoi viiny [Refugees in Ukraine during the First World War] (O. P. Reient, Ed.). Problemy istorï Ukrä̈ni XIX - počatku XX st. Problems of the History of Ukraine of XIX-beginning XX cc., (4), 111-132. [in Ukrainian]

Shcherov, I. P. (2000). Migratsionnaya politika v Rossii. 1914 - 1922 gg. [Migration policy in Russia. 1914 - 1922]. Smolensk: Smolensk State Pedagogical Institute, 314 p. [in Russian].

Thorpe, J. (2011). Displacing Empire. Refugee Welfare, National Activism and State Legitimacy in Austria-Hungary in the First World War. Refugees and the End of Empire. Imperial Collapse and Forced Migration in the Twentieth Century, 102-126. London: Palgrave Macmillan doi: https://doi.org/10.1057/9780230305700 [in English]

Tsentralnyi derzhavnyi istorychnyi arkhiv Ukrainy, m. Kyiv. [Central State Historical Archive of Ukraine in Kyiv-CSHAUK]

Tsentralnyi derzhavnyi istorychnyi arkhiv Ukrainy, m. Lviv. [Central State Historical Archive of Ukraine in Lviv-CSH $\boldsymbol{A U L}]$

Tsovyan, D. G. (2005). Deyatelnost gosudarstvennykh organov i obshchestvennykh organizatsiy po okazaniyu pomoshchi bezhentsam v gody Pervoy mirovoy voyny. $1914-1917$ gg. [The Activity of State Bodies and Community Organizations to Assist Refugees during the First World War. 1914 - 1917] (Candidate's thesis). Moscow. [in Russian]

Zakony (1916). Zakony i rasporyazheniya o bezhentsakh [Refugee laws and regulations]. (Vol. 1). Moscow: Mysl, 63 p. [in Russian]

Zhvanko, L. (2019). Mizhnarodno-pravovi instrumenty OON v konteksti vyrishennia hlobalnoi problemy bizhentsiv ta mihrantiv [UN International Legal Instruments in the Context of Addressing the Global Refugee and Migrant Problem]. European Historical Studies, 14, 83-100. doi: http://doi.org/10.17721/2524-048X.2019.14.83-100 [in Ukrainian]

Zhvanko, L. M. (2012). Bizhentsi Pershoi svitovoi viiny: ukrainskyi vymir (1914 - 1918 roky) [Refugees of the First World War: the Ukrainian Reality]. Kharkiv: Virovets A. P. “Apostrof”, 568 p. [in Ukrainian]

The article was received on January 05, 2020. Article recommended for publishing 17/02/2021. 